\title{
Seismic Analysis of 3D Framed Building
}

\author{
S. Venkatesh ${ }^{1}$, Ms. T. Savithra ${ }^{2}$ \\ ${ }^{1}$ Department of Civil Engineering, Sir Vishveshwaraiah Institute of Science \& Technology, Andhra Pradesh, \\ India \\ ${ }^{2}$ M.E (Assistant Professor), Department of Civil Engineering, Sir Vishveshwaraiah Institute of Science \& \\ Technology, Andhra Pradesh, India
}

\begin{abstract}
Article Info

Volume 8, Issue 6

Page Number : 404-410

Publication Issue

November-December-2021

Article History

Accepted : 05 Dec 2021

Published : 16 Dec 2021

Generally RC framed structures are designed without regards to structural action of masonry infill walls present. Masonry infill walls are widely used as partitions. These buildings are generally designed as framed structures without regard to structural action of masonry infill walls. They are considered as non- structural elements. RC frame building with open first storey is known as soft storey, which performs poorly during strong earthquake shaking. Past earthquakes are evident that collapses due to soft storeys are most often in RC buildings. In the soft storey, columns are severely stressed and unable to provide adequate shear resistance during the earthquake. Hence a combination of two structural system components i.e. Rigid frames and RC shear walls or Rigid frames and Bracings leads to a highly efficient system in which shear wall and bracings resist the majority of the lateral loads and the frame supports majority of the gravity loads.
\end{abstract}

Keywords : 3D Framed Building, Rigid frames, Bracings leads

\section{INTRODUCTION}

The capacity of structural members to undergo inelastic deformations governs the structural behaviour and damageability of multi-storey buildings during earthquake ground motions. From this point of view, the evaluation and design of buildings should be based on the inelastic deformations demanded by earthquakes, besides the stresses induced by the equivalent static forces as specified in several seismic regulations and codes. Although, the current practice for earthquakeresistant design is mainly governed by the principles of force-based seismic design, there have been significant attempts to incorporate the concepts of deformation-based seismic design and evaluation into the earthquake engineering practice. In general, the study of the inelastic seismic responses of buildings is not only useful to improve the guidelines and code provisions for minimizing the potential damage of buildings, but also important to provide economical design by making use of the reserved strength of the building as it experiences inelastic deformations. In recent seismic guidelines and codes in Europe and USA, the inelastic responses of the building are 
determined using nonlinear static methods of analysis known as the pushover methods.

\section{LITERATURE REVIEW}

Sharany Haque, Khan Mahmud Amanat, "Seismic Vulnerability of columns of RC frame buildings with soft ground storey". Earthquake vulnerability of buildings with open ground floors is well known around the world. However, under the present socio economic context of developing nations like Bangladesh, construction of such buildings is unavoidable. In such a situation, an investigation has been performed to study the behaviour of such buildings subjected to earthquake load so that some guideline could be developed to minimize the risk involved in such type of buildings. It has been found that code provisions do not provide any guideline in this regard. Present study reveals that such types of buildings should not be treated as ordinary RC framed buildings. It has been found that calculation of earthquake forces by treating them as ordinary frames results in an underestimation of base shear.

\subsection{LINEAR STATIC ANALYSIS}

This method is perhaps the simplest procedure at disposal for a structural engineer to perform an earthquake analysis and achieve reasonable results. It is prescribed in any relevant code for earthquake analysis and is widely used especially for building and other common structures meeting certain regularity conditions. The method is also called "The Lateral Forced Method" as the effects of $n$ earthquake are assumed to be the same as the once resulting from the statical transverse loadings. If the structural response is not significantly affected by contributions from higher modes of vibration it is reasonable to assume that with an appropriate set of inertia forces one may achieve a good approximation for the response. This is the basic concept of the "Equivalent Static Method".

\section{Effect of Shear Wall}

Shear wall is a structural element used to resist horizontal forces parallel to the plane of the wall. Shear wall has highly in plane stiffness and strength which can be used to simultaneously resist large horizontal loads and support gravity loads. Shear Walls are specially designed structural walls include in the buildings to resist horizontal forces that are induces in the plane of the wall

due to wind, earthquake, and other forces. They are mainly flexural members and usually provided in high rise buildings to avoid the total collapse of the high-rise buildings under seismic forces.

These walls generally start at foundation level and are continuous throughout the building height. Their thickness can be as low as $150 \mathrm{~mm}$, or as high as $400 \mathrm{~mm}$ in high rise buildings. Shear walls are usually provided along both length and width of buildings (Figure 1). Shear walls are like vertically oriented wide beams that carry earthquake loads downwards to the foundation.

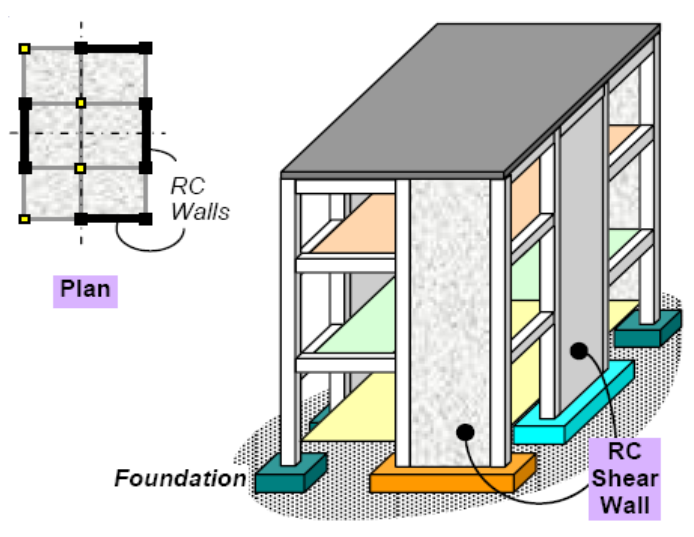

Fig 1: Shear walls in building

\subsection{PERFORMED ANALYSIS IN ETABS AND SAP2000}

The analysis of building is carried out using ETABS AND SAP2000 computer program. The following topics describe some of the important areas in the modelling.

Defining of the wall and slab sections: 
1.In the present analysis all the walls are modelled as four-node quadrilateral shell element and slabs are modelled as membrane element. The slab sections are modelled as rigid diaphragms by using the rigid diaphragm option in the assign menu. By modelling the slab as rigid diaphragms the masses of the floor are automatically lumped at their centre of gravity.

2.Further the brick masonry infill walls are modelled as equivalent double diagonal strut for second category of models using the expression given by Stafford Smith (1996) and Hendry (1998).

\section{Equivalent Static Analysis:}

The fundamental natural time period of building is calculated by expression given in IS1893-2002. The Lateral load calculation and its distribution is done along the height as per IS1893-2002.The Seismic weight calculated considering full dead load and 50\% live load.

Further the analysis also performed in ETABS9.7 nonlinear and SAP2000v15.

\section{RESULTS AND DISCUSSIONS}

\subsection{NATURAL PERIODS}

All objects (including buildings and the ground) have a "natural period," or the time it takes to swing back and forth, from point $A$ to point $B$ and back again. If you pushed the flag pole shown in Figure-6.1, it would sway at its natural period.

As seismic waves move through the ground, the ground also moves at its natural period. This can become a problem if the period of the ground is the same as that of a building on the ground. When a building and the ground sway or vibrate at the same rate, they are said to resonate. When a building and the ground resonate it can mean disaster. This is because, as the building and ground resonate.

One of the most important factors affecting the period is height. A taller building will swing back and forth more slowly (or for a longer period) than a shorter one. For example, a 4-story building might have a natural period of 0.5 seconds, while a 60 -story building may have a period of as much as 7 seconds. Building height can have dramatic effects on a structure's performance in an earthquake. A taller building often suffers more damage than shorter one because the natural period of the ground tends to match that of buildings nine stories or taller. This explains why some buildings are severely damaged and others are not.

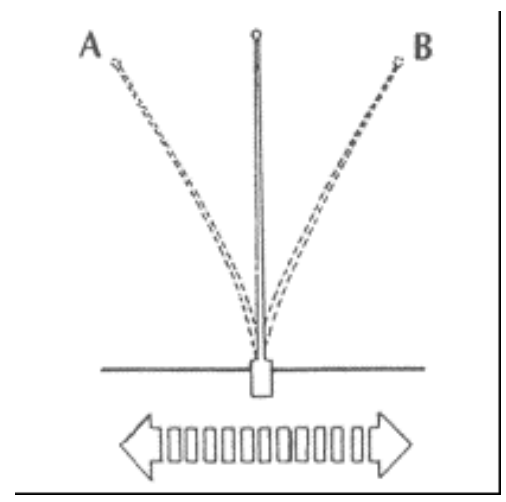

Fig 1:Flag pole

Table 3.1 : Comparison of time period between IS code method and using ETABS for various building models

\begin{tabular}{|c|c|c|c|c|}
\hline & \multicolumn{2}{|c|}{ IS CODE Method } & \multicolumn{2}{c|}{ ETABS Analysis } \\
\hline $\begin{array}{c}\text { Mod } \\
\text { el No }\end{array}$ & $\begin{array}{c}\text { Longitudi } \\
\text { nal }\end{array}$ & $\begin{array}{c}\text { Transver } \\
\text { se }\end{array}$ & $\begin{array}{c}\text { Longitudi } \\
\text { nal }\end{array}$ & $\begin{array}{c}\text { Transver } \\
\text { se }\end{array}$ \\
\hline $\mathbf{1}$ & 1.25 & 1.25 & 1.6541 & 1.6541 \\
\hline $\mathbf{2}$ & 0.765 & 0.855 & 0.5482 & 0.5482 \\
\hline $\mathbf{3}$ & 0.765 & 0.855 & 0.7610 & 0.7610 \\
\hline $\mathbf{4}$ & 0.765 & 0.855 & 0.4684 & 0.4684 \\
\hline $\mathbf{5}$ & 0.765 & 0.855 & 0.4493 & 0.4493 \\
\hline $\mathbf{6}$ & 0.765 & 0.855 & 0.4925 & 0.4925 \\
\hline $\mathbf{7}$ & 0.765 & 0.855 & 0.5537 & 0.5537 \\
\hline $\mathbf{8}$ & 0.765 & 0.855 & 0.5412 & 0.5412 \\
\hline
\end{tabular}




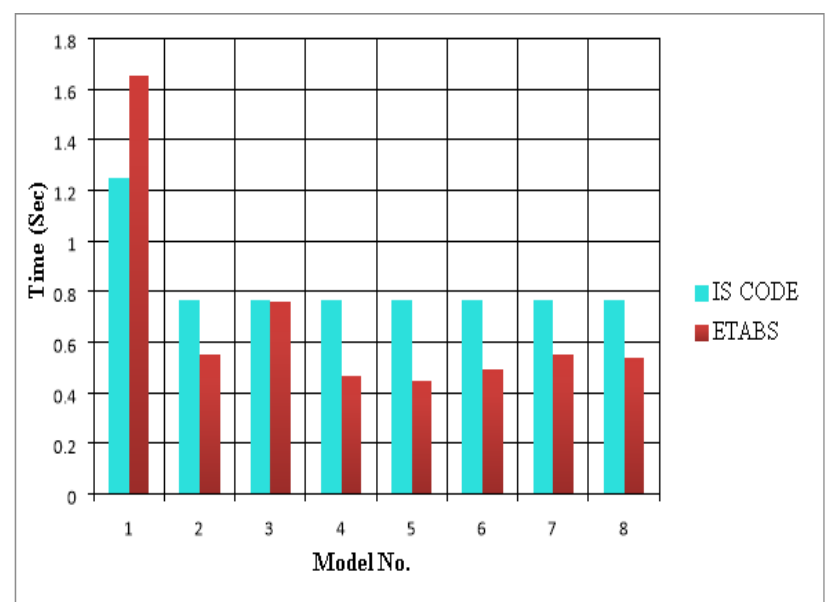

Chart : Model Vs Time period for different building models along longitudinal direction.

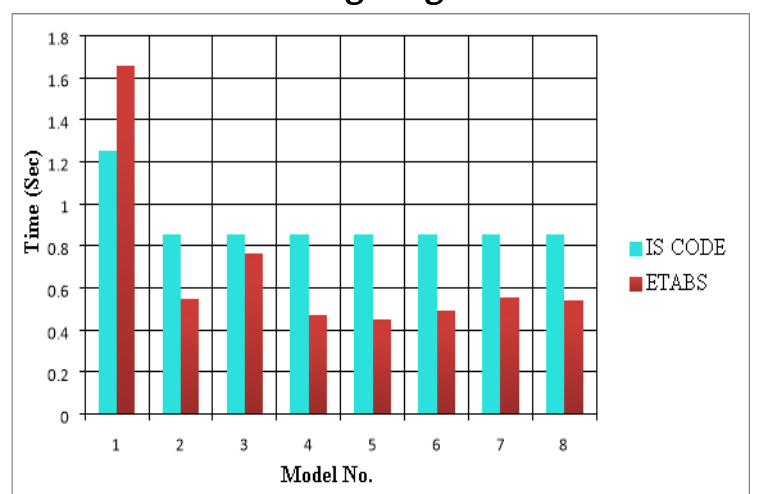

Chart : Model Vs Time period for different building models along transverse direction.

From above table 3.1, it is observed that the time periods obtained by IS code and by ETABS analysis are differing. The table shows natural period for bare frame model from ETABS is $24.4 \%$ is more than the IS code method. For models with soft storey i.e. models 3 obtained from ETABS are more than that of obtained from IS code method. for models with shear walls i.e. model 4,5 , and 6 time period obtained from ETABS is reduced by $38.8 \%, 41.26 \%$ and $35.62 \%$ respectively as compared with IS code procedure. For concrete bracings models i.e. Model 7 and 8 the time period obtained by ETABS is reduced by $27.62 \%$ and $29.25 \%$ as compared with time period obtained by Is Code procedure.

For soft storey Model the fundamental natural time period is increased by $27.96 \%$ in case of EATBS analysis when compared with full infill brick model.
From the above discussion IS Code procedure is not giving any suitable guidance to calculate fundamental

natural time period for soft storey building, shear wall as well as bracings systems. Both lateral load resisting element i.e. Shear wall and Concrete bracings system impart much stiffness to model when they are subjected to seismic loading.

\subsection{BASE SHEAR (KN) AND DISPLACEMENT (mm) AT YIELD POINT}

Base shear and displacement for various models along longitudinal and transverse direction are shown in table 6.31 and 6.32. From the tables, it can be observed that for models along longitudinal direction the base shear is more and yield displacement is more along transverse direction.

For model 5 gives maximum base shear and model 1 gives maximum displacement along longitudinal and transverse direction.

Table : Base shear and displacements along longitudinal direction.

\begin{tabular}{|c|c|c|}
\hline \multirow{2}{*}{$\begin{array}{c}\text { Model } \\
\text { No. }\end{array}$} & \multicolumn{2}{|c|}{ with infill } \\
\cline { 2 - 3 } & $\begin{array}{c}\text { Base Shear at } \\
\text { first hinge (KN) }\end{array}$ & $\begin{array}{c}\text { Displacement at } \\
\text { First hinge (mm) }\end{array}$ \\
\hline 1 & 10486.955 & 50 \\
\hline 2 & 29723.035 & 31.5 \\
\hline 3 & 16394.046 & 19.7 \\
\hline 4 & 28913.484 & 20.1 \\
\hline 5 & 29771.912 & 19.5 \\
\hline 6 & 23390.486 & 17.7 \\
\hline 7 & 24712.302 & 24.1 \\
\hline 8 & 24645.644 & 22.2 \\
\hline
\end{tabular}


Table: Base shear and displacements along transverse direction.

\begin{tabular}{|c|c|c|}
\hline \multirow{2}{*}{$\begin{array}{c}\text { Model } \\
\text { No. }\end{array}$} & $\begin{array}{c}|c| \\
\text { Base Shear at first } \\
\text { hinge (KN) }\end{array}$ & $\begin{array}{c}\text { Dinfill } \\
\text { First hinge (mm) }\end{array}$ \\
\cline { 2 - 3 } & 9037.417 & 53 \\
\hline 1 & 28570.998 & 36.8 \\
\hline 2 & 11871.906 & 23.7 \\
\hline 3 & 29507.687 & 28.3 \\
\hline 4 & 28891.64 & 26.3 \\
\hline 5 & 21437.533 & 23.1 \\
\hline 6 & 23230.695 & 31.9 \\
\hline 7 & 23811.191 & 32.2 \\
\hline 8 & & \\
\hline
\end{tabular}

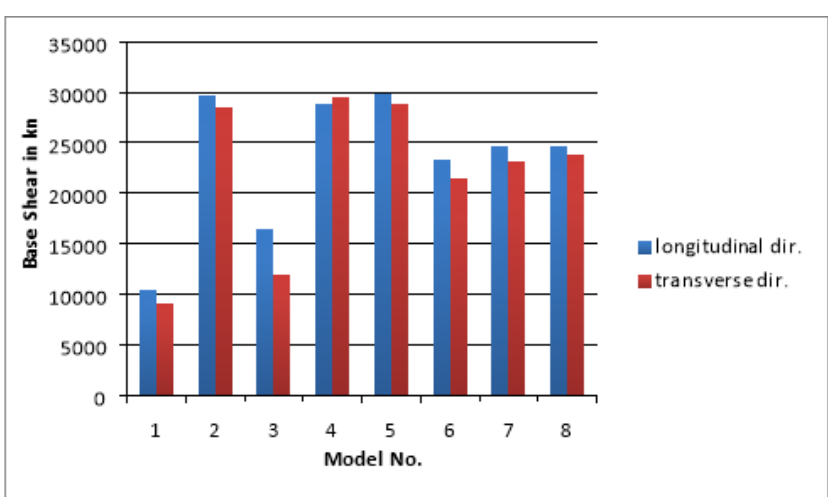

Chart: Comparison of base Shear at first hinge for various models along longitudinal and transverse direction.

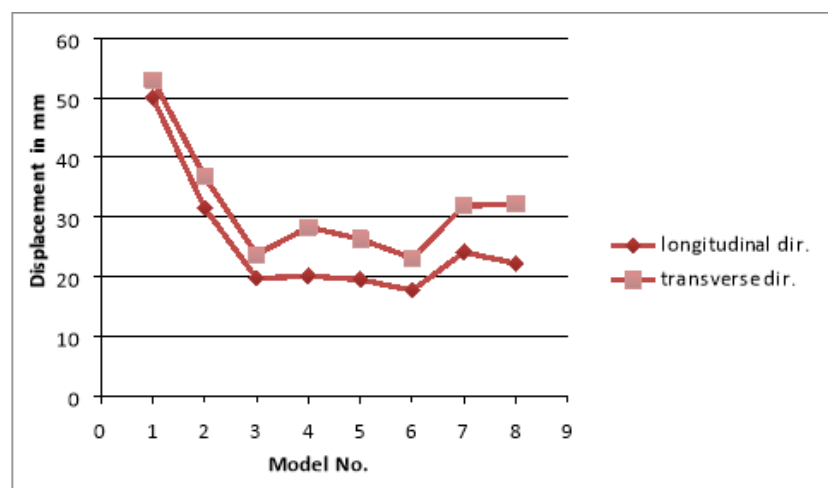

Chart : Comparison of Displacement at first hinge for various models along longitudinal and transverse direction.

\section{STRUCTURAL RESPONSE}

To examine the hinge status and deformations of different building models, pushover analysis is done along the longitudinal and transverse directions from all models and the Results are presented in Tables below.

Model 1: First hinge is formed at storey 1 at the corner, roof displacement at first hinge is $50 \mathrm{~mm}$ along longitudinal direction and $53 \mathrm{~mm}$ along transverse direction. Hinge status remains within B-IO-LS-CPC-D.

Model 2: First hinge is formed at storey 1 at the corner, roof displacement at first hinge is $31.5 \mathrm{~mm}$ along longitudinal direction and $36.8 \mathrm{~mm}$ along transverse direction. Hinge status remains within BIO-LS-CP-C.

Model 3: First hinge is formed at storey 1 at the corner, roof displacement at first hinge is $19.7 \mathrm{~mm}$ along longitudinal direction and $23.7 \mathrm{~mm}$ along transverse direction. Hinge status remains within BIO-LS-CP-C.

Model 4: First hinge is formed at storey 1 at the corner, roof displacement at first hinge is $20.1 \mathrm{~mm}$ along longitudinal direction and $28.3 \mathrm{~mm}$ along transverse direction. Hinge status remains within BIO-LS-CP-C.

\subsection{NONLINEAR STATIC PUSHOVER ANALYSIS}

The recent advent of performance based design has brought the nonlinear static pushover analysis procedure to the forefront. Pushover analysis is a static, nonlinear procedure in which the magnitude of the structural loading is incrementally increased in accordance with a certain predefined pattern. With the increase in the magnitude of the loading, weak links and failure modes of the structure are found. The loading is monotonic with the effects of the cyclic behaviour and load reversals being estimated by using a modified monotonic force-deformation criteria and with damping approximations. Static pushover analysis is an attempt by the structural engineerig profession to evaluate the real strength of 
the structure and it promises to be a useful and effective tool for performance based design.

Pushover analysis is a nonlinear static method of analysis. This analysis technique, also known as sequential yield analysis or simply "Pushover" analysis has gained significant popularity during past few years. It is one of the three analysis techniques recommended by FEMA 273/274 and a main component of Capacity Spectrum Analysis method (ATC-40). The static pushover analysis is becoming a popular tool for seismic performance evaluation of existing and new structures. The expectation is that the pushover analysis will provide adequate information on seismic demands imposed by the design ground motion on the structural system and its components.

\subsection{Performance Point}

It is the point where capacity spectrum intersects the appropriate demand spectrum (capacity equals demand). To have desired performance, every structure has to be designed for this level of forces. Desired performance with different damping ratios have been shown in Fig.4.1

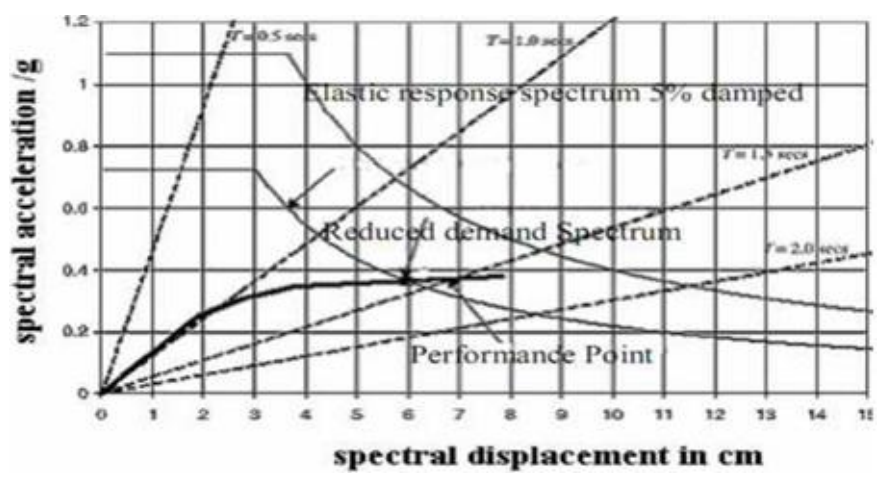

Figure 4.1 : Determination of performance point

\subsection{Building Performance Levels}

Building performance is a combination of the performance of both structural and nonstructural components. Different building performance levels, used to describe the performance of buildings in pushover analysis are described below.

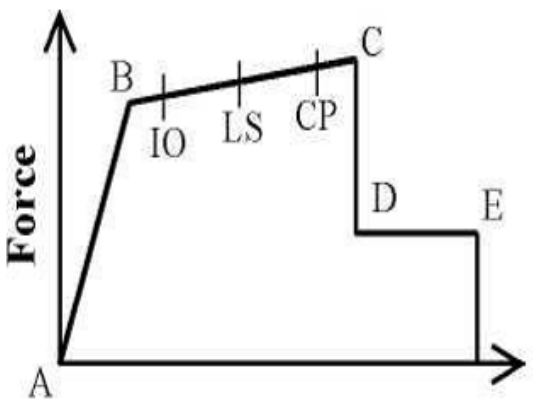

BYield Stress

IO-Immediate occupancy

LS-Life Safety

CP-Collapse prevention C-Collapse

Fig 4.2 : Force Deformation for pushover hinge

\section{v. CONCLUSIONS}

$\checkmark$ Fundamental natural period decreases when effect of infill wall, concrete shear wall and concrete bracings are considered.

$\checkmark$ As the soft stories Exist at Ground storey, the fundamental time period of the structure is increases; hence existence soft storey can make the structure to be flexible in nature.

$\checkmark \quad$ The seismic base shear obtained by IS Code is not in a good agreement with the values obtained from Equivalent static and Response spectrum analysis using ETABS.

$\checkmark$ Seismic base shear considerably more for masonry infill, shear wall and Concrete bracings models as

$\checkmark$ compared with bare frame model. Hence consideration of masonry infill stiffness, shear wall and Concrete bracings increases Strength of the structure.

$\checkmark$ Storey drifts are found within the limit as specified by code (IS 1893-2002 Part-1).

The formation of first hinge is not early in models with shear wall as compared with bottom soft storey and bare frame even base shear is also more for shear wall models.

\section{ACKNOWLEDGEMENT}

We sincerely thanks to our chairman Sri. M Prabhakar Reddy GARU for fostering an excellent 
academic environment and labs during our project work

We sincerely thank Dr. B.D. Venkatramana Reddy M.Tech., Ph.D., and Director of our college for his suggestions during our project work. We sincerely thank Dr. V. Senthil Murugan M.E, Ph.D., and principal of our college for fostering an excellent academic environment and for his suggestions during our project work.

We are grateful to Mr. R. Surya Prakash M.E, Head of the Department for his support guidance, valuable suggestions, and uninterrupted cooperation during our project work.

\section{REFERENCES}

[1]. Shaik Kamal Mohammed Azam and Vinod Hosur. "Seismic behaviour of multi-storeyed buildings with soft intermediate storey". Journal of Structural Engineering Vol. 39, No. 3, August-September 2012 pp. 237-245.

[2]. Jaswant N. Arlekar, Sudhir K. Jain and C.V.R. Murty. "Seismic Response of RC Frame Buildings with Soft First Storeys". Proceedings of the CBRI Golden Jubilee Conference on Natural Hazards in Urban Habitat, 1997, New Delhi.

[3]. Murthy, C.V.R., and Jain, S.K., "Experimental investigation of RC frames with brick masonry infill walls having central opening subjected to cyclic displacement loading".

[4]. Amit V. Khandve. "Seismic Response of RC Frame Buildings with Soft Storeys". International Journal of Engineering Research and Applications (IJERA) ISSN: 2248-9622 www.ijera.com Vol. 2, Issue 3, May-Jun 2012, pp.2100-2108.

[5]. Sharany Haque, Khan Mahmud Amanat, "Seismic Vulnerability of columns of RC frames buildings with soft ground storey".
International journal of mathematical models and method in applied sciences.

\section{Cite this article as :}

S. Venkatesh, Ms. T. Savithra, "Seismic Analysis of 3D Framed Building ", International Journal of Scientific Research in Science and Technology (IJSRST), Online ISSN : 2395-602X, Print ISSN : 2395-6011, Volume 8 Issue 6, pp. 404-410, November-December 2021. Available at doi : https://doi.org/10.32628/IJSRST218656 Journal URL : https://ijsrst.com/IJSRST218656 